\title{
PENGARUH PERSEPSI GURU TERHADAP KEPEMIMPINAN KEPALA MADRASAH, MOTIVASI KERJA DAN KOIMPETENSI GURU TERHADAP KINERJA GURU DI MADRASAH TSANAWIYAH NEGERI SE-KABUPATEN SAMBAS
}

\author{
Kaspullah $^{1}$, Purniadi ${ }^{2}$, Imelda ${ }^{3}$ \\ Pascasarjana Prodi Magister Pendidikan Agama Islam, IAIS Sambas \\ Institut Agama Islam Sultan Muhammad Syafiuddin Sambas
}

\begin{abstract}
This study aims to determine (1) describe and analyze teachers' perceptions of headmaster leadership, teacher work motivation, teacher competence, teacher performance and (5) the influence of principal leadership, teacher motivation and competence on teacher performance in Madrasah Tsanawiyah throughout the district. Sambas.The research method is quantitative descriptive associative causal (cause-effect). The study population was 133 madrasah principals and all teachers in Sambas District MTs. Data collection using a questionnaire method. Test the validity of the instrument with the product moment analysis technique, while the reliability test with the alpha coefficient. The data analysis technique used multiple regression analysis. The results showed that: (1) there is an effect of teacher perceptions of principal leadership on teacher performance with a significance value of 0.00 which is indicated by a value of 0.356 meaning that it implies that $35.60 \%$. (2) there is a positive and significant effect of work motivation on teacher performance with a significance value of 0.00 , contributing $47.10 \%$ (3) there is a positive and significant effect of teacher competence on teacher performance with a significance value of 0.00 which contributes $31.20 \%$. The research implication of the findings of this study requires efforts to improve teacher performance including; planning, organizing, directing, coordinating and supervising all educational activities held in schools, providing incentives for high-achieving teachers, sending teachers to take part in trainings including training in making learning program tools and training in using technological media, attending MGBS (Teacher Deliberation Field of Study) deliberation with the aim of unifying, evaluating and finding solutions to deficiencies in the teaching and learning process. add new knowledge by using print or mass media.
\end{abstract}

Keywords: Teachers' Perceptions of Madrasah Principal Leadership, Work Motivation, Teacher Competence, and Teacher Performanc

\section{PENDAHULUAN}

\section{A. Latar Belakang}

Pemimpin mempunyai masa dan masa telah melahirkan para pemimpin. ${ }^{1}$ Pemimpin yang baik akan menghasilkan sumber daya manusia unggul, berkualitas dan

'Zafri Zamzam, Syekh Muhammad Arsyad Al-Banjary: Sebagai Ulama Juru Da'wah Sejarah Penyiaran Islam di Kalimantan Abad 13 H/18 M dan Pengaruhnya di Asia Tenggara (Banjarmasin: Antasari Press, 2018), hlm. 2. 
mumpuni. ${ }^{2}$ Dalam ruang lingkup pendidikan formal, kepala sekolah merupakan salah satu komponen yang terpenting bagi kemajuan suatu bangsa. Tanpa kepala sekolah, maka sekolah tidak mempunyai visi dan misi ke depan. Pengaruh yang begitu kuat bagi kepemimpinan kepala sekolah untuk meningkatkan kualitas dalam pendidikan, bertanggung jawab atas penyelenggaraan pemberdayaan tenaga kependidikan dan sarana prasarana yang dimiliki oleh sekolah sebagai penunjang keberhasilan dari proses belajar mengajar. ${ }^{3}$ Amanah yang begitu besar yang diberikan oleh negara dan amanah dari masyarakat, sehingga kepala sekolah bukanlah dikatakan sebagai penguasa yang menguasai bawahannya, tetapi kepala sekolah adalah melayani bawahanbawahannya ${ }^{4}$ Segala-galanya keperluan sekolah dan proses belajar mengajar di sekolah tidak terlepas dari peran kepala sekolah.

Kepala sekolah yang bertugas sebagai administrasi pendidikan, edukatif dari proses belajar mengajar yang dilakukan oleh guru. ${ }^{5}$ Tugas kepala sekolah sebagai administratif adalah melakukan pengontrolan terhadap guru agar apa yang dikerjakannya sesuai dan tepat dengan sasaran. Sementara, sebagai administrator bahwa kepala sekolah mempunyai visi untuk memajukan sekolah bersama para guru. Tugas-tugas lainnya yang dilaksanakan oleh kepala sekolah mencakup merencanakan, mengorganisasikan, mengarahkan, mengkoordinasikan, mengawasi, mengevaluasi seluruh kegiatan sekolah, seperti proses belajar mengajar, administrasi kantor, siswa, pegawai, perlengkapan, keuangan, perpustakaan dan administrasi hubungan kemasyarakatan. ${ }^{6}$ Tugas dan tanggung jawab kepala sekolah tersebut adalah untuk mencapai kesuksesan sekolah yang dipimpinnya, baik dalam hal kerjasama maupun hubungan yang baik dengan guru.

Makna kepemimpinan dalam al-Qur'an jika berkaitan dengan kepemimpinan tentang pendidikan di sekolah adalah kepala sekolah. Sebagai kepala sekolah, maka peran sebagai pemimpin, baik sebagai leader, menjadi barometer dalam pengelolaan proses pembelajaran di sekolah, sebagai teladan bagi bawahannya. Menurut Mulyasa, ${ }^{7}$ kepribadian kepala sekolah sebagai leader akan tercermin dari sifat yang dimilikinya, seperti jujur, percaya diri, tanggung jawab, berani mengambil resiko dan keputusan, berjiwa besar, emosi yang stabil dan teladan. Keberhasilan dari kepemimpinan kepala

${ }^{2}$ Nyoto, Buku Ajar Manajemen Sumber Daya Manusia (Ponorogo, Indonesia: Uwais Inspirasi Indonesia, 2019), hlm. 1.Marihot Tua Efendi Hariandja, Manajemen Sumber Daya Manusia: Pengadaan, Pengembangan, Pengkompensasian, dan Peningkatan Produktivitas Pegawai (Jakarta: Grasindo, 2002), hlm. 1. Sekolah."

${ }^{3}$ Anwar, "Pengelolaan Pembiayaan Pendidikan: Studi Efektifitas Kepemimpinan Kepala

${ }^{4}$ Suparman, Kepemimpinan Kepala Sekolah dan Guru: Sebuah Pengantar Teoritik (Indonesia: Uwais Inspirasi Indonesia, 2019), hlm. 5.

${ }^{5}$ Atiqullah, "Kepemimpinan Kepala Sekolah Dalam Mengelola Kelas Unggulan," Nuansa 8, no. 1 (2011): hlm. 89.

${ }^{6}$ Burhanuddin, Analisis Administrasi, Mmanajemen dan Kepemimpinan Pendidikan (Jakarta: Bumi Aksara, 2014), hlm. 29. 34.

${ }^{7}$ Mulyasa, Menjadi Kepala Sekolah Profesional (Bandung: PT. Remaja Rosda Karya, 2007), hlm. 
sekolah tergantung dari gaya kepala sekolah dalam memimpin, baik gaya instruksi, konsultasi, pastisipasi, delegasi dan gaya lainnya. ${ }^{8}$

Kepala sekolah dalam memimpin bawahan-bawahannya harus saling bekerjasama agar tujuan yang ingin dicapai secara bersama-sama sesuai dengan visi dan misi sekolah yang bersangkutan. Akan tetapi, tidak semuanya kerjasama antara guru itu berjalan dengan baik, karena setiap tujuan mempunyai hambatan dan hambatannya adalah motivasi.

Motivasi adalah dorongan dalam diri dan luar diri seseorang untuk melakukan sesuatu, baik secara internal maupun external. ${ }^{9}$ Motivasi sangat mempengaruhi produktivitas kerja, sehingga selalu erat kaitannya bahwa motivasi yang tinggi akan menghasilkan produktivitas tinggi dan motivasi yang rendah akan menurunkan produktivitas. Ada beberapa faktor yang mempengaruhi motivasi, yaitu gaya kepemimpinan, administrator, sikap individu dan situasi kerja. ${ }^{10}$ Motivasi intrinsik yang dimiliki maka hambatan untuk menggapai cita-cita bersama dengan kepala sekolah tidak ada sama sekali hambatan, sementara hambatan yang terbesarnya adalah motivasi extrinsik, sehingga sebagai kepala sekolah harus bisa mengatasi dari hambatan tersebut, misalnya melakukan pelatihan-pelatihan untuk meningkatkan kompetensi guru dalam mengajar.

Kompetensi adalah kemampuan dalam hal penguasaan pengetahuan, keterampilan dan sikap yang ditampilkan melalui unjuk kerja yang dicapai setelah menyelesaikan suatu program pendidikan. ${ }^{11}$ Untuk mendapat kemampuan tersebut maka diperoleh melalui pendidikan, pelatihan dan belajar mandiri dengan memanfaatkan sumber belajar. ${ }^{12}$ Progam-program dari pelatihan yang dilakukan atas inisiatif kepala sekolah sehingga dapat meningkatkan kompetensi yang dimiliki oleh guru dan dapat meningkatkan kinerja guru. Kinerja berasal dari kata performance atau unjuk kerja. ${ }^{13}$ Menurut Usman, kinerja adalah hasil kerja yang telah dicapai oleh seseorang dalam bidang tugasnya. ${ }^{14}$ Guru menampilkan kinerja yang baik, maka tidak terlepas dari kepemimpinan.

Madrasah Tsanawiyah Negeri Kabupaten Sambas menuntut agar guru lebih dapat melakukan banyak penelitian dalam kegiatan belajar mengajar, mengembangkan diri, membuat artikel, dan membuat karya ilmiah sebagai salah satu pelaksanaan dalam kinerja

${ }^{8}$ Fitriyasni dan Marlis Safrida, "Pengaruh Gaya Kepemimpinan Partisipatif Kepala Sekolah Terhadap Motivasi Kerja Guru," FITRA 3, no. 2 (2017): hlm. 68.

${ }^{9}$ Hamzah B. Uno, Teori Motivasi dan Pengukurannya (Jakarta: Bumi Aksara, 2009), 72.A.M Sardiman, Interaksi dan Motivasi Belajar Mengajar (Jakarta: CV. Rajawali, 2006), hlm. 73.

${ }^{10}$ Sudarman Danim, Kepemimpinan Pendidikan Kepemimpinan Jenius $(I Q+E Q)$, Etika, Perilaku Motivasional, dan Mitos (Bandung: Alfabeta, 2010), hlm. 109.

${ }^{11}$ J.B. Situmorang dan Winarno, Pendidikan Profesi dan Sertifikasi Pendidik (Klaten: Macanan Jaya Cemerlang, 2008), hlm. 17.Jamil Suprihatiningkrum, Guru Profesional: Pedoman Kinerja, Kualifikasi \& Kompetensi Guru (Yogyakarta: Ar-Ruz Media, 2014), hlm. 97.

${ }^{12}$ Jejen Musfah, Peningkatan Kompetensi Guru: Melalaui Pelatihan dan Sumber Belajar Teori dan Praktik (Jakarta: Kencana, 2012), hlm. 27.

${ }^{13}$ Rusman, Manajemen Kurikulum (Jakarta: Rajawali Pers, 2009), hlm. 5.

${ }^{14}$ Husaini Usman, Manajemen: Teori, Praktik dan Riset Pendidikan (Jakarta: Bumi Aksara, 2008), hlm. 487. 
guru. Namun, sebagian guru MTs Negeri Kabupaten Sambas ${ }^{15}$ masih mengalami 3 kesulitan dalam mengembangkan dirinya. Hal ini disebabkan antara lain guru di MTs Negeri Kabupaten Sambas mayoritas sudah memasuki usia lanjut, kurangnya hubungan antara kepala sekolah dan guru, dan kurangnya motivasi yang diberikan kepala sekolah terhadap guru. Ada beberapa hasil observasi di MTs Negeri Kabupaten Sambas; Pertama MTs Negeri Kabupaten Sambas, guru belum dapat bekerja secara maksimal terhadap siswa karena masih banyak guru yang sering meninggalkan siswa pada saat pelajaran di kelas dan hanya memberikan tugas, terlebih pada pelajaran praktik banyak guru yang tidak selalu mendampingi siswanya. Kedua guru MTs Negeri Kabupaten Sambas kurang menggunakan media sebagai bahan pembelajaran. Ketiga kepemimpinan yang belum aktif dari seorang guru ketika di kelas, hal ini maksudnya ketika seorang guru sedang di dalam kelas suasana kelas terkesan membosankan dan banyak siswa yang tidak bergairah ketika menerima pelajaran tersebut.

Dengan demikian, keberhasilan kepemimpinan kepala sekolah tidak bisa juga dilepaskan bagaimana persepsi guru dalam menanggapinya. Karena, kepemimpinan kepala sekolah tidak dapat sepenuhnya dijadikan patokan keberhasilan dalam kepemimpinannya. Dengan adanya standar motivasi kerja dan kompetensi guru yang dapat dijadikan pedoman untuk mengukur keberhasilan dalam kepemimpinan kepala sekolah. Adapun tujuan dalam penelitian ini diantarany; (1) mendiskripsikan dan menganalisis persepsi guru terhadap kepemimpinan kepala madrasah terhadap kinerja guru, (2) mendiskripsikan dan menganalisis motivasi kerja guru terhadap kinerja guru, (3) mendiskripsikan dan menganalisis kompetensi guru terhadap kinerja guru dan (4) mengetahui dan menganalisis seberapa besar pengaruh secara bersama-sama kepemimpinan kepala madrasah, Motivasi dan Kompetensi Guru terhadap Kinerja Guru di Madrasah Tsanawiyah Negeri Se-Kabupaten Sambas.

\section{METODE PENELITIAN}

Penelitian ini menggunakan metode kuantitatif deskriptif dengan jenis penelitian asosiatif kausal (sebab-akibat). Adapun lokasi penelitian pada MTs Negeri Se-Kabupaten Sambas yang terdiri dari 4 Madrasah Tsanawiyah Negeri. Populasi dalam penelitian ini adalah seluruh guru MTs Negeri Kabupaten Sambas yang berjumlah 133 orang termasuk Kepala Sekolah dan guru tidak tetap (GTT). Sampel yang digunakan dalam penelitian ini menggunakan teknik Probability Sampling. Probability Sampling adalah teknik pengambilan sampel yang memberikan peluang yang sama bagi setiap unsur (anggota) populasi untuk dipilih menjadi anggota sampel. ${ }^{16}$ Teknik pengumpulan data yang digunakan dalam penelitian ini terdiri dari kuesioner, wawancara dan observasi. Sebelum instrumen atau alat ukur digunakan untuk mengumpulkan data penelitian, maka perlu dilakukan uji coba kuesioner untuk mencari kevalidan dan reliabilitas alat ukur tersebut.

\footnotetext{
${ }^{15}$ Hasil Observasi di MTs Negeri Kabupaten Sambas, pada tanggal 5 Januari 2020

${ }^{16}$ Sugiyono, Metode Penelitian Pendidikan; Pendekatan Kuantitatif, Kualitatif dan R\&D, hlm 120.
} 
Uji validitas berguna untuk mengetahui apakah alat ukur tersebut valid. Menurut Sugiono ${ }^{17}$ mengatakan valid berarti instrumen tersebut dapat digunakan untuk mengukur apa yang seharusnya diukur. Teknik analisis data dalam penelitian ini menggunakan teknis analisis data regresi sederhana dan regresi berganda dengan bantuan SPSS Windows versi 23. Adapun tahap pelaksananan analisis meliputi : (1) analisis deskriptif, (2) uji persyaratan analisis, (3) uji asumsi klasik, dan (4) uji hipotesis.

\section{KAJIAN TEORI}

\section{A. Persepsi Guru}

Persepsi berasal dari bahasa Inggris artinya perception yang artinya tanggapan, daya untuk memahami sesuatu. ${ }^{18}$ Persepsi adalah sebuah proses individu dalam menginterpretasikan, mengorganisasikan dan memberi makna terhadap stimulus yang berasal dari lingkungan dimana individu itu berada yang diperoleh dari pengalaman. ${ }^{19}$

Persepsi dipengaruhi oleh beberapa faktor diantaranya;

1. Objek yang dipersepsi. Objek yang menimbulkan stimulus baik berasal dari panca indera maupun reseptor. Persepsi dapat juga dari dalam individu maupun luar individu yang mempersepsi langsung mengenai syaraf penerima yang bekerja sebagai reseptor;

2. Alat indera, syarat dan susunan syaraf indera yang merupakan alat untuk menerima stimulus dan syaraf, yakni otak sebagai pusat kesadaran. Sebagai alat untuk mengadakan respon diperlukan motoris yang dapat membentuk persepsi seseorang;

3. Perhatian untuk menyadari atau dalam mengadakan persepsi diperlukan adanya perhatian, yaitu merupakan tingkah laku utama sebagai suatu persiapan dalam rangka mengadakan persepsi. ${ }^{20}$

Berdasarkan dari teori di atas bahwa persepsi guru merupakan pendapat dari setiap guru dalam melaksanakan suatu kegiatan yang didapatkan dari setiap pengalaman seseorang kemudian persepsi tersebut diungkapkan secara langsung dan diungkapkan.

\section{B. Kepemimpinan Kepala Sekolah}

Kepemimpinan adalah seseorang yang dapat mempengaruhi orang lain. Oleh karena itu, untuk mempengaruhi orang lain, pemimpin harus mempunyai seni atau kemampuan untuk mengkoordinasikan dan menggerakkan seorang individu atau sekelompok ke arah pencapaian yang diharapkan. ${ }^{21}$

Beberapa unsur dari seorang pemimpin, diantaranya;

1. Ada orang yang memimpin, mempengaruhi dan memberikan bimbingan;

\footnotetext{
${ }^{17}$ Sugiyono, Metode Penelitian Pendidikan; Pendekatan Kuantitatif, Kualitatif dan R\&D, hlm 173.

${ }^{18}$ Alwi Hasan, dkk, Kamus Besar Bahasa Indonesia (Jakarta: Departemen Pendidikan Nasional Balai Pustaka, 2005), hlm. 759.

${ }^{19}$ Mohammad Asrori, Psikologi Pembelajaran (Bandung: CV. Wacana Prima, 2009), hlm. 214.

${ }^{20 B i m o}$ Walgito, Pengantar Psikologi Umum (Surabaya: Bina Ilmu, 2004), hlm. 70.

${ }^{21}$ Muchlish Huda, "Tugas Kepemimpinan Kepala Sekolah Dalam Manajemen Berbasis Sekolah," al-Afkar, Journal for Islamic Studies 1, no. 2 (2018): hlm. 46-54.
} 
2. Ada orang yang dipengaruhi atau pengikat seperti pada anggota organisasi, bawahan atau kelompok yang bisa dikendalikan;

3. Adanya kegiatan tertentu dalam menggerakkan bawahan untuk mencapai tujuan bersama;

4. Adanya tujuan yang diperjuangkan melalui serangkaian tindakan. ${ }^{22}$

Kepemimpinan kepala sekolah cara atau kepala sekolah dalam mempengaruhi, mendorong, membimbing, mengarahkan dan menggerakkan guru, staf, orang tua siswa, dan pihak-pihak yang terkait untuk bekerja sesuai dengan tujuan. ${ }^{23}$ Tugas kepala sekolah sebagai pemimpin menurut Mulyasa ${ }^{24}$ diantaranya;

1. Mampu memperdayakan guru-guru untuk melaksanakan proses pembelajaran dengan baik, lancar dan produktif. Pertama, kepala sekolah harus berusaha untuk menggerakkan tim evaluasi belajar bagi peserta ddiik untuk lebih giat dalam belajar dan kemudian hasilnya bisa diumumkan secara terbuka dan diperlihatkan dipapan pengumuman. Kedua, menggunakan waktu belajar yang efektif di sekolah dengan cara mendorong guru untuk memulai dan mengakhiri pembelajaran sesuai dengan waktu yang telah ditentukan serta memanfaatkannya secara efektif dan efisien untuk kepentingan pembelajaran.

2. Kepala sekolah sebagai manajer. Dalam hal ini kepala sekolah harus memiliki rencana yang strategis melalui kerjasama demi peningkatan profesionalisme guru yang mengajar di sekolah tersebut.

3. Kepala sekolah sebagai administrator. Tugas kepala sekolah sebagai administrator sangat erat kaitannya dengan administrasi. Tugas-tugas tersebut adalah; Pertama, kemampuan mengelola administrasi personalia diwujudkan dalam penyusunan kelengkapan data. Kedua, kemampuan mengelola administrasi keuangan harus diwujudkan dalam pengembangan administrasi keuangan rutin. Ketiga, pengembangan administrasi keuangan yang bersumber dari masyarakat dan orang tua peserta didik. Keempat, pengembangan administrasi keuangan yang bersumber dari pemerintah yakni uang yang harus dipertanggungjawabkan dan dana bantuan operasional. Pengembangan proposal untuk mendapatkan bantuan keuangan, seperti hibah. Kelima, pengembangan proposal untuk mencari berbagai kemungkinan dalam mendapatkan bantuan keuangan dari pihak yang tidak terikat.

4. Kepala sekolah sebagai supervisor. Dalam rangka mewujudkan tujuan dari kegiatan pembelajaran sehingga seluruh aktivitas organisasi sekolah harus bermuara pada pencapaian efisiensi dan efektivitas pembelajaran, sehingga supervisor yang dimiliki oleh kepala sekolah adalah mensupervisi pekerjaan yang dilakukan oleh tenaga kependidikan. Pada pelaksanaannya, kepala sekolah harus memperhatikan prinsipprinsip; Pertama, hubungan konsultasi, kolegial dan bukan hiarkhis. Kedua, dilaksanakan secara demokratis. Ketiga, berpusat kepada tenaga kependidikan, yakni

\footnotetext{
${ }^{22}$ Huda, hlm. 47.

${ }^{23}$ Huda, hlm. 48.

${ }^{24}$ Mulyasa, Menjadi Kepala Sekolah Profesional. andung: PT. Remaja Rosda Karya, (2007), hlm.
} 90. 
guru. Keempat, dilakukan berdasarkan kebutuhan tenaga kependidikan. Kelima, merupakan bantuan professional, yang dilakukan melalui diskusi kelompok, kunjungan kelas, pembicaraan individual dan simulasi pembelajaran.

5. Kepala sekolah sebagai inovator. Kepala sekolah harus memiliki strategi yang tepat untuk menjalin hubungan yang harmonis dengan lingkungan, mencari gagasan baru, mengintegrasikan setiap kegiatan, memberikan teladan kepada seluruh tenaga kependidikan di sekolah.

6. Kepala sekolah sebagai motivator. Kepala sekolah harus memiliki strategi yang tepat untuk memberikan motivasi kepada tenaga kependidikan dalam melaksanakan tugas dan fungsinya dengan cara menumbuhkan motivasi melalui pengaturan lingkungan fisik, pengaturan suasana kerja, disiplin, dorongan, penghargaan secara efektif dan penyediaan berbagai sumber belajar melalui pengembangan pusat sumber belajar.

7. Kepala sekolah sebagai leader. Sebagai leader, kepala sekolah dapat dianalis dari kepribadian, yang tercermin dari sifat jujur, percaya diri, tanggung jawab, berani mengambil resiko dan keputusan, berjiwa besar, emosi yang stabil dan teladan. ${ }^{25}$

Berdasarkan dari beberapa pendapat di atas kepemimpinan kepala sekolah merupakan cara seorang pemimpin di lembaga pendidikan mempengaruhi guru dalam memberikan motivasi, bimbingan atau pengarahan agar tercapai tujuan.

\section{Motivasi Kerja Guru}

Motivasi berasal dari bahasa latin, dikenal dengan "Movere"yang artinya menggerakkan. ${ }^{26}$ Motivasi sangat mempengaruhi dalam kehidupan manusia, lebih-lebih lagi bagi seorang guru dalam melaksanakan tugas dan tanggung jawabnya sebagai pendidik. ${ }^{27}$ Motivasi sangat penting dimiliki oleh guru karena tanpa adanya motivasi, maka keefektifan dalam belajar tidak dapat dicapai sesuai dengan apa yang diharapkan. Oleh karena itu, motivasi yang dimiliki terdiri dari dua, yakni intrinsik dan ekstrinsik. Menurut Abraham Maslow ${ }^{28}$ meyakini bahwa pada dasarnya manusia itu baik dan menunjukkan bahwa individu memiliki dorongan yang tumbuh secara terus menerus yang memiliki potensi besar. Sistem hirarki kebutuhan, merupakan pola yang biasa digunakan untuk menggolongkan motif manusia. Sistem hirarki kebutuhan meliputi lima kategori motif yang disusun dari kebutuhan yang paling rendah yang harus dipenuhi terlebih dahulu sebelum memenuhi kebutuhan yang lebih tinggi.

\footnotetext{
${ }^{25}$ Atiqullah, "Kepemimpinan Kepala Sekolah Dalam Mengelola Kelas Unggulan.”Huda, “Tugas Kepemimpinan Kepala Sekolah Dalam Manajemen Berbasis Sekolah."

${ }^{26}$ Sardiman, Interaksi dan Motivasi Belajar Mengajar.

${ }^{27}$ Muhammad Izzuddin Taufiq, Panduan Lengkap dan Praktis Psikogi Islam (Jakarta: Gema Insani Press, 2006), hlm. 696.

${ }^{28}$ Tri Andjarwati, "Motivasi dari Sudut Pandang Teori Hirarki Kebutuhan Maslow, Teori Dua Faktor Herzberg, Teori X Y Mc Gregor, dan Teori Motivasi Prestasi Mc Clelland," JMM17 Jurnal Ilmu Ekonomi \& Manajemen 1, no. 1 (2015): hlm 48.
} 
Hubungan motivasi dengan kegiatan belajar di sekolah, erat kaitannya dengan tujuan yang ingin dicapai oleh seorang siswa melalui kegiatan belajar yang sedang diikutinya. ${ }^{29}$ Unsur-unsur dari motivasi intrinsik diantarnaya;

1. Dorongan ingin tahu dan ingin menyelidiki dunia yang lebih luas;

2. Adanya sifat positif dan kreatif yang ada pada diri manusia dan keinginan untuk maju;

3. Adanya keinginan untuk mencapai prestasi sehingga mendapat dukungan dari orangorang penting, misalkan orangtua, saudara, guru, atau teman-teman, dan lain sebagainya;

4. Adanya kebutuhan untuk menguasai ilmu atau pengetahuan yang berguna bagi dirinya, dan lain-lain.

Sementara, motivasi ekstrinsik adalah faktor yang datang dari luar diri individu tetapi memberi pengaruh terhadap kemauan untuk belajar. Seperti pujian, peraturan, tata tertib, teladan guru, orangtua, dan lain sebagainya. Kurangnya respons dari lingkungan secara positif akan memengaruhi semangat belajar seseorang menjadi lemah. ${ }^{30}$ Bentuk untuk membangkitkan motivasi ekstrinsik dalam kegiatan belajar mengajar, seperti pujian dan hadiah, peraturan/tata tertib sekolah, sikap teladan dan orang tua, guru dan seterusnya merupakan contoh-contoh konkret motivasi ekstrinsik yang dapat menolong siswa dalam belajar. ${ }^{31}$

Menurut Purwanto, motivasi extrinsik terdiri dari tiga golongan, diantaranya;

1. Motif atau kebutuhan organis, misalnya kebutuhan untuk makan, kebutuhan untuk bernafas;

2. Motif darurat misalnya, dorongan untuk menyelamatkan diri, dorongan untuk membalas, dorongan untuk berusaha;

3. Motif obyektif, yang menyangkut kebutuhan untuk melakukan manipulasi untuk menarik perhatian. ${ }^{32}$

Motivasi guru adalah semangat seorang guru dalam mendapatkan sesuatu yang akan dicapai dengan adanya faktor intrinsik dan ekstrinsik dengan motif ingin mendapatkan gaji, pujian, tata tertib, teladan guru dan sebagainya.

\section{Kompetensi Guru}

Kompetensi guru merupakan perpaduan antara kemampuan personal, keilmuan, teknologi, sosial dan spiritual yang secara kafah membentuk kompetensi standar profesi guru, yang mencakup penguasaan materi, pemahaman terhadap peserta didik, pembelajaran yang mendidik, pegembangan pribadi dan profesional. Kompetensi terkait erat dengan standar. Seseorang disebut kompeten dalam bidangnya jika pengetahu an, keterampilan, sikapnya, dan hasil kerjanya sesuai standar yang ditetapkan. ${ }^{33}$ Menurut

${ }^{29}$ A. Ahmadi, Pendidikan Dari Masa Ke Masa (Bandung: CV Armiko, 1987), hlm. 109.

${ }^{30}$ Baharuddin dan Esa Nur Wahyuni, Teori Belajar \& Pembelajaran (Yogyakarta: Ar-Ruz Media, 2010), hlm. 22-24.

${ }^{31}$ Muhibinsyah, Psikologi Belajar (Jakarta: Logos, 1999), hlm. 137.

${ }^{32}$ Ngalim Purwanto, Psikologi Pendidikan (Bandung: Remaja Rosdakarya, 2006), hlm. 64.

${ }^{33}$ Jejen Musfah, Peningkatan Kompetensi Guru (Jakarta: Kencana, 2011), hlm. 27-28. 
Peraturan Pemerintah No19 Tahun 2005 tentang Standar Nasional Pendidikan, kompetensi guru terdiri dari kompetensi pedagogis, kepribadian, sosial, dan profesional.

Kemampuan pedagogis adalahKemampuan dalam mengelola peserta didik yang meliputi: (1) pemahaman wawasan atau landasan kependidikan; (2) pemahaman tentang peserta didik; (3) pengembangan kurikulum/silabus; (4) perancangan pembelajaran; (5) pelaksanaan pembelajaran yang mendidik dan dialogis; (6) evaluasi hasil belajar; dan (7) pengembangan peserta didik untuk mngaktualisasikan berbagai potensi yang dimilikinya. ${ }^{34}$ Kompetensi personal berkaitan langsung dengan rhomaterial personaliti, artinya bahwa suatu personaliti profesi yang memiliki ketahanan diri dalam menghadapi goncangan profesi. Dalam ranah ini kompetensi kepribadian melingkupi kemampuan kepribadian seseorang profesional yang mantap, berakhlak mulia, berwibawa, dan teladan bagi lingkungan kerja dan masyarakat. ${ }^{35}$ Menurut Badan Standar Nasional, kompetensi kepribadian yaitu "kemampuan kepribadian yang: (1) berakhlak mulia; (2) mantap, stabil, dan dewasa; (3) arif dan bijaksana; (4) menjadi teladan; (5) mengevaluasi kinerja sendiri; (6) mengembangkan diri; dan (7) religious." Sekurang-kurangnya kompetensi kepribadian meliputi beriman dan bertaqwa, berakhlak mulia, arif dan bijaksana, demokratis, mantap, berwibawa, stabil, dewasa, jujur, sportif, menjadi teladan bagi peserta didik dan masyarakat, secara objektif mengevaluasi kinerja sendiri dan mengembangkan diri secara mandiri dan berkelanjutan. ${ }^{36}$

Kompetensi sosial adalah "kemampuan guru untuk berkomunikasi dan berinteraksi secara efektif dan efisien dengan peserta didik, sesama guru, orangtua/wali peserta didik, dan masyarakat sekitar". ${ }^{37}$ Kompetens profesional mencakup tentang kemampuan penguasaan materi pembelajaran secara luas dan mendalam yang meliputi: (1) konsep, struktur, dan metode keilmuan/teknologi/seni yang menaungi/koheren dengan materi ajar; (2) materi ajar yang ada dalam kurikulum sekolah; (3) hubungan konsep antar mata pelajaran terkait; (4) penerapan konsep keilmuan dalam kehidupan sehari-hari; dan (5) kompetisi secara professional dalam konteks global dengan tetap melestarikan nilai dan budaya nasional. ${ }^{38}$ Adapun, ciri-ciri guru profesional, diantaranya; (1) Kemampuan intelektual melalui pendidikan, (2) Mengetahui pengetahuan spesialisasi, (3) Menjadi anggota organisasi profesi, (4) Memiliki pengetahuan praktis yang dapat digunakan langsung oleh orang lain atau klien, (5) Memiliki teknik kerja yang dapat dikomunikasikan, (6) Memiliki kapasitas mengorganisasikan kerja secara mandiri, (7) Mementingkan kepentingan orang lain, (8) Memiliki kode etik, (9) Memiliki sanksi dan

\footnotetext{
${ }^{34}$ Barnawi dan Mohammad Ariffin, Etika dan Profesi Kependidikan (Yogyakarta: Ar-Ruz Media, 2012), hlm. 121.

${ }^{35}$ Triamto, Pengantar Penelitian Pendidikan bagi Pengembangan Profesi Pendidikan \&Tenaga Kependidikan (Jakarta: Kencana, 2011), hlm. 22.

${ }^{36}$ Triamto, hlm. 54-55.

${ }^{37}$ Moh Uzer Usman, Menjadi Guru Profesional (Bandung: Rosdakarya, 2005), hlm. 122.

${ }^{38}$ Musfah, Peningkatan Kompetensi Guru, hlm. 54-55.
} 
tanggung jawab komunitas, (10) Mempunyai sistem upah budaya profesional, (l) Melaksanakan pertemuan profesional tahunan. ${ }^{39}$

Kompetensi guru adalah kemampuan yang dimiliki oleh seorang guru sebagai pendidik untuk mentransfer ilmu kepada peserta didik. Kompetensi guru tersebut merupakan kelebihan yang dimiliki setiap guru.

\section{HASIL PENELITIAN DAN PEMBAHASAN}

\section{Pengaruh Persepsi Guru Terhadap Kepemimpinan Kepala Madrasah} Berpengaruh Terhadap Kinerja Guru di MTs Negeri Kabupaten Sambas

Dalam hasil penelitian ini menunjukkan bahwa terdapat pengaruh pengaruh persepsi guru terhadap kepemimpinan kepala Madrasah terhadap kinerja guru dengan nilai signifikansinya sebesar 0.00 yang mana $\mathrm{p}=0,00<0,05 \mathrm{H}_{\mathrm{o}}$ di ditolak dan $\mathrm{H}_{1}$ terima, jadi terdapat pengaruh yang signifikan dari persepsi guru terhadap kepemimpinan kepala sekolah terhadap kinerja guru. Sedangkan besarnya korelasi koefisien pengaruh persepsi guru terhadap kepemimpinan kepala Madrasah $\left(\mathrm{X}_{1}\right)$ terhadap kinerja guru $(\mathrm{Y})$. Selain itu besarnya nilai pengaruh persepsi guru terhadap kepemimpinan kepala sekolah sebesar 0,356 artinya mengandung pengertian bahwa 35,60\% sumbangan persepsi guru terhadap kepemimpinan kepala sekolah terhadap kinerja guru, sedangkan sisanya 64,4\% yang dipengaruhi oleh faktor yang lain (100\%-35,6\%).

Berdasarkan hasil penelitian di atas, sesuai dengan kinerja guru yang memiliki empat aspek terdiri dari kemampuan, penerimaan, tujuan sekolah, tujuan yang ingin dicapai, interaksi antara tujuan dan kemampuan para karyawan (guru) dalam sekolah, masing-masing elemen berpengaruh terhadap kinerja guru. ${ }^{40}$ Namun, dari aspek kinerja guru berdasarkan hasil penelitian berpengaruh signifikan terhadap kepemimpinan kepala sekolah. ${ }^{41}$ Hal ini juga diperkuat oleh penelitian yang dilakukan oleh Lusiana, ${ }^{42}$ yang mana persepsi guru tentang kepemimpinan kepala sekolah berada pada kategori baik yaitu pada rata-rata skor 25,777, kinerja guru tergolong dalam kategori sangat baik yaitu pada rata-rata skor 51,76 persepsi guru tentang kepemimpinan kepala sekolah terhadap kinerja guru tidak berpengaruh secara signifikan ditunjukkan $p$-value $=0,092>\alpha=0.05$. Sementara, pengaruh yang lain dari kepemimpinan kepala sekolah terhadap persepsi guru

${ }^{39}$ Sudarwan Danim, Pengembangan Profesi Guru (Jakarta: Kencana, 2011), hlm. 106-8.

${ }^{40}$ Fery Desrian Octama, 'Pengaruh Persepsi Guru Tentang Kepemimpinan Kepala Sekolah, Komunikasi, Dan Motivasi Terhadap Kinerja Guru SMP Negeri 1 Batu Brak Lampung Barat' (unpublished Skripsi di Publikasikan, Lampung, Fakultas Keguraan dan Pendidikan, 2018) <http://digilib.unila.ac.id/31202/> [accessed 27 July 2020].

${ }^{41}$ Satria Mulyawan, 'Pengaruh Persepsi Kepemimpinan Kepala Sekolah Dan Motivasi Kerja Terhadap Kinerja Guru Ekonomi SMA Kota Tegal' (unpublished PhD Thesis, Universitas Negeri Semarang, 2011).

42 Ni Putu Mega Lusiana, 'Pengaruh Persepsi Guru Tentang Kepemimpinan Kepala Sekolah Terhadap Kinerja Guru Di Sma Laboratorium Undiksha Singaraja Tahun Pelajaran 2017', Jurnal Pendidikan Ekonomi Undiksha, 10.2 (2019), 440-49 <https://doi.org/10.23887/jjpe.v10i2.20076>. 
disebabkan oleh persoalan tentang supervisi kepala sekolah, lingkungan kerja, kompensasi guru dan melakukan pelatihan diklat. ${ }^{43}$

Berdasarkan dari hasil temuan penelitian di MTs Negeri Kabupaten Sambas menyebutkan bahwa persepsi guru terhadap kepemimpinan kepala sekolah berpengaruh terhadap kinerja guru di MTs Negeri Kabupaten Sambas dengan nilai signifikansinya sebesar 0.00. Selain itu untuk skor persepsi guru terhadap kepemimpinan kepala sekolah yang paling banyak memilih kategori sedang yaitu berjumlah 111 orang. Dengan demikian hasil analisis penelitian memberikan fakta bahwa persepsi guru terhadap kepemimpinan kepala sekolah menunjukkan bahwa kualitas kepemimpinan kepala sekolah MTs Negeri Kabupaten Sambas sudah tidak diragukan lagi, dengan kualifikasi pendidikan yang memenuhi syarat untuk menjabat sebagai kepala sekolah, selain itu kepala sekolah MTs Negeri Kabupaten Sambas mampu menjalankan fungsinya dengan sangat baik dan mampu menciptakan suasana yang kondusif di sekolah, hal tersebut sangat dibutuhkan oleh sekolah demi terwujudnya mutu sekolah sesuai dengan tujuan. Hal ini juga diperkuat oleh penelitian Alimi ${ }^{44}$ ada perbedaan yang signifikan dalam persepsi guru tentang efektivitas kepemimpinan kepala sekolah di sekolah menengah negeri dan swasta, dengan kepala sekolah menengah negeri memiliki tingkat efektivitas kepemimpinan yang rendah dalam efektivitas keterampilan hubungan pedagogis dan hubungan masyarakat, tetapi administrasi yang tinggi keefektifan keterampilan sementara yang sebaliknya terjadi di sekolah menengah swasta. Penelitian ini juga didukung oleh pendapat Hoy dan Miskel $^{45}$ bahwa efektivitas seorang guru bekerja dicirikan dengan empat dimensi, yakni adaptation, goal attainment, integration, and latency. Adaptation menyangkut usaha suatu organisasi menyesuaikan diri dengan lingkungan di tempatnya berada.

\section{Pengaruh Motivasi Kerja Terhadap Kinerja Guru}

Dalam hasil penelitian ini menunjukkan bahwa terdapat pengaruh motivasi kerja terhadap kinerja guru dengan nilai signifikansinya sebesar 0.00 yang mana $p=0,00<0,05$ $\mathrm{H}_{\mathrm{o}}$ di ditolak dan $\mathrm{H}_{1}$ terima, jadi terdapat pengaruh yang signifikan dari motivasi kerja terhadap kinerja guru. Sedangkan besarnya korelasi koefisien pengaruh motivasi kerja $\left(\mathrm{X}_{2}\right)$ terhadap kinerja guru $(\mathrm{Y})$ sebesar 0.471 artinya pengaruh antara variabel motivasi

${ }^{43}$ Laeli Kurniati, 'Pengaruh Supervisi Kepala Sekolah Dan Motivasi Kerja Terhadap Kinerja Guru SMK Negeri 1 Purbalingga' (unpublished PhD Thesis, Universitas Negeri Semarang, 2007). Rahmawati Setia Utami and Tarsis Tarmudji, 'Pengaruh Lingkungan Kerja Dan Kompensasi Kerja Melalui Motivasi Kerja Sebagai Variabel Intervening Terhadap Kinerja Guru Di SMA Negeri 7 Semarang Pada Tahun 2013/2014', Economic Education Analysis Journal, 3.2 (2014). Djati Handajani, 'Analisis Peningkatan Kinerja Guru Berdasarkan Diklat Dan Kompensasi Melalui Kepuasan Kerja Sebagai Variabel Intervening (Studi Kasus Pada Smp Negeri Sub Rayon Jakenan Kabupaten Pati)' (unpublished Masters, Universitas Muria Kudus, 2016) <http://eprints.umk.ac.id> [accessed 28 July 2020].

44 Alimi, 'Teachers' Perception of Principals' Leadership Effectiveness in Public and Private Secondary Schools in Ondo State', 2011, 7 (p. hlm 22).

${ }^{45}$ Ermi Sola, 'SEBUAH REFLEKSI : Efektivitas Kerja Pimpinan', Idaarah: Jurnal Manajemen Pendidikan, 1.2 (2017), p. hlm 243 <https://doi.org/10.24252/idaarah.v1i2.4267>. 
kerja $\left(\mathrm{X}_{2}\right)$ terhadap kinerja guru $(\mathrm{Y})$ artinya memiliki kekutan pengaruh antara variabel motivasi kerja $\left(\mathrm{X}_{2}\right)$ terhadap kinerja guru $(\mathrm{Y})$.

Dari hasil perhitungan uji t pengaruh motivasi kerja terhadap kinerja guru diperoleh hasil t-hitung sebesar $47.10 \%$ dengan nilai signifikasi $0,000<0,05$, berarti motivasi kerja berpengaruh positif dan signifikan terhadap kinerja guru. Hasil penelitian ini dapat membuktikan hipotesis bahwa: motivasi kerja berpengaruh terhadap kinerja guru MTs Negeri Kabupaten Sambas.

Sesuai dengan hasil penelitian yang dilakukan diperkuat oleh teori dari hasil penelitian yang dilakukan oleh Ardiana, ${ }^{46}$ Dita Anggrayni, Hery Sawiji, dan Susantiningrum, ${ }^{47}$ bahwa motivasi kerja mempunyai pengaruh yang positif bagi kinerja guru. Motivasi kerja yang tinggi yang dilakuan oleh guru, maka mempengaruhi kinerja guru. Penelitian ini dilakukan pada guru SMK Akuntansi di Kota Madiun. Hipotesis yang mengatakan bahwa motivasi kerja memiliki pengaruh positif dan signifikan terhadap kinerja guru dapat diterima dan terbukti benar, dimana variable motivasi kerja memiliki pengaruh positif terhadap kinerja guru. ${ }^{48}$ Sesuai dengan pendapat Robbins ${ }^{49}$ menyebutkan tentang motivasi sebagai proses yang menunjukkan intensitas individu, arah, dan ketekunan dari upaya menuju pencapaian tujuan. Motivasi adalah dorongan dasar yang menggerakan seseorang bertingkah laku. Dorongan ini berada pada diri seseorang yang menggerakan untuk melakukan sesuatu yang sesuai dengan dorongan dalam dirinya. Oleh karena itu, perbuatan sesorang yang didasarkan atas motivasi tertentu mengandung tema sesuai dengan motivasi yang mendasarinya.

Hasil ini relevan dengan hasil beberapa penelitian Bentea, Robbins and Judge ${ }^{50}$ yang mengarah pada kesimpulan pengaruh kepuasan dan motivasi terhadap kinerja guru Hasil ini juga cocok dengan beberapa pendapat ahli yang menyatakan keterkaitannya kepuasan dan kinerja. Faktor-faktor yang mempengaruhi kinerja termasuk pembelajaran, motivasi, kepribadian, emosi, persepsi, pelatihan, efektivitas kepemimpinan, pekerjaan kepuasan, pengambilan keputusan individu, penilaian kinerja, pengukuran sikap, seleksi karyawan, desain kerja dan stres kerja.

\footnotetext{
46 Titin Eka Ardiana, 'Pengaruh Motivasi Kerja Guru Terhadap Kinerja Guru Akuntansi SMK di Kota Madiun', JURNAL AKUNTANSI DAN PAJAK, 17.02 (2017) <https://doi.org/10.29040/jap.v17i02.11>.

${ }^{47}$ Dita Anggrayni, Hery Sawiji, and Susantiningrum Susantiningrum, 'Pengaruh Motivasi Kerja Dan Lingkungan Kerja Terhadap Kinerja Guru SMK Pancasila 6 Jatisrono Kecamatan Jatisrono Kabupaten Wonogiri', JIKAP (Jurnal Informasi Dan Komunikasi Administrasi Perkantoran), 2.2 (2018) <https://jurnal.uns.ac.id/JIKAP/article/view/20800> [accessed 30 July 2020].

${ }^{48}$ Slamet Riyadi and Aria Mulyapradana, 'Pengaruh Motivasi Kerja Terhadap Kinerja Guru Radhatul Atfal di Kota Pekalongan', Jurnal LITBANG Kota Pekalongan, 13 (2017), 106-17.

${ }^{49}$ Anis Syamsu Rizal, 'Pengaruh Motivasi Kerja dan Kedisiplinan Terhadap Kinerja Guru SMP', Jurnal Ulul Albab, 23.1 (2019), 15 (p. hlm 17) <https://doi.org/10.31764/jua.v23i1.658>.

${ }^{50}$ Rasto Rasto and Siti Yulianti Maulani, 'Satisfaction and Motivation as Determinants of Teacher Performance', Jurnal Pendidikan Bisnis Dan Manajemen, 5.1 (2019), 11-21 (p. hlm 18) <https://doi.org/10.17977/um003v5i12019p011>.
} 


\section{Pengaruh Kompetensi guru (X3) Terhadap Kinerja Guru (Y) di MTs Negeri Kabupaten Sambas}

Dalam hasil penelitian ini menunjukkan bahwa terdapat pengaruh kompetensi guru terhadap kinerja guru dengan nilai signifikansinya sebesar 0.00 yang mana $p=0,00<0,05$ $\mathrm{H}_{\mathrm{o}}$ di ditolak dan $\mathrm{H}_{1}$ terima, jadi terdapat pengaruh yang signifikan dari kompetensi guru terhadap kinerja guru. Sedangkan besarnya korelasi koefisien pengaruh kompetensi guru(X3) terhadap kinerja guru (Y) sebesar 0.312 artinya pengaruh antara variabel kompetensi guru(X3) terhadap kinerja guru (Y) artinya memiliki kekutan pengaruh antara variabel kompetensi guru (X3) terhadap kinerja guru (Y). Sesuai dengan hasil penelitian secara teori bahwa menurut Hary Susanto, ${ }^{51}$ kompetensi guru terhadap motivasi mempunyai pengaruh yang signifikan. Dalam hal ini juga menunjukkan tentang kinerja guru yang baik maka kompetensi guru juga ikut baik. Hasil penelitian ini diperkuat dengan teori Gibson ${ }^{52}$ bahwa kinerja seseorang ditentukan oleh kemampuan (kompetensi) untuk melaksanakan pekerjaan. Standar kompetensi yang dimiliki guru telah diatur dalam Undang-Undang Nomor 14 Tahun 2005 tentang Standar Nasional Pendidikan bahwa secara tegas menyatakan bahwa ada empat kompetensi yang harus dimiliki guru, salah satunya adalah kompetensi profesional. Dalam pengembangan bidang pendidikan, tenaga guru sebagai unsur dominan dalam proses pembelajaran diarahkan untuk meningkatkan kualitas dan profesionalisme.

Mulyasa $^{53}$ mengemukakan kompetensi guru merupakan perpaduan antara kemampuan personal, keilmuan, teknologi, sosial, dan spritual yang secara kaffah membentuk kompetensi standar profesi guru, yang mencakup penguasaan materi, pemahaman terhadap peserta didik, pembelajaran yang mendidik, pengembangan pribadi dan profesionalisme. Menurut Castetter mengemukakan ada empat kriteria kinerja dalam Mulyasa $^{54}$, 1) Karakteristik individu, 2) Proses, 3) Hasil, dan 4) Kombinasi antara karakter individu, proses, dan hasil. Kinerja seseorang dapat ditingkatkan bila ada kesesuaian antara pekerjaan dengan keahliannya, begitu pula halnya dengan penempatan guru pada bidang tugasnya. Menempatkan guru sesuai dengan keahliannya secara mutlak harus dilakukan. Bila guru diberikan tugas yang tidak sesuai dengan keahliannya akan berakibat menurunnya cara kerja dan hasil pekerjaan mereka, juga akan menimbulkan rasa tidak puas pada diri mereka. Rasa kecewa akan menghambat perkembangan moral kerja guru. Berdasarkan dari hasil penelitian tentang kompetensi guru terhadap kinerja guru di MTs Negeri Kabupaten Sambas dapat disimpulkan bahwa sudah baik di mana

${ }^{51}$ Hary Susanto, 'Faktor-Faktor Yang Mempengaruhi Kinerja Guru Sekolah Menengah Kejuruan', Jurnal Pendidikan Vokasi, 2.2 (2012) <https://doi.org/10.21831/jpv.v2i2.1028>.

${ }^{52}$ Komang Septia Cahya Ningrum, 'Pengaruh Kompetensi Guru Terhadap Kinerja Guru SMP Negeri 6 Singaraja', 7 (2016), 12.

${ }^{53}$ H Ade Sobandi, 'Pengaruh Kompetensi Guru Terhadap Kinerja Mengajar Guru SMKN Bidang Keahlian Bisnis dan Manajemen di Kota Bandung', 9.17 (2010), 10 (p. hlm.31).

54 lilik Kurniasih, 'Pengaruh Kompetensi Guru, Iklim Organisasi dan Supervisi Akademik Kepala Sekolah Terhadap Kinerja Guru Mata Pelajaran Pendidikan Agama Islam Sekolah Dasar Negeri SeKecamatan Sukoharjo Tahun Pelajaran 2017/ 2018', 187 (p. hlm.118). 
hampir sebagian kompetensi hal ini terjadi karena MTs Negeri Kabupaten Sambas selalu berupaya untuk mengembangkan kompetensi guru sesuai dengan kurikulum yang berlaku dan melakukan inovasi-inovasi terbaru dalam mengembangkan kompetensi yang dimilikinya.

\section{Pengaruh Persepsi Guru Tentang Kepemimpinan Kepala Madrasah, Motivasi Kerja, Kompetensi Guru terhadap kinerja Guru di Madrasah Tsanawiyah Negeri Se-Kabupaten Sambas}

Dalam hasil penelitian ini menunjukkan bahwa terdapat pengaruh persepsi guru tentang kepemimpinan kepala madrasah, motivasi kerja, kompetensi guru terhadap kinerja Guru secara bersama dengan nilai signifikansinya sebesar 0.035 yang mana $\mathrm{p}=$ $0,035<0,05 \mathrm{H}_{\mathrm{o}}$ di ditolak dan $\mathrm{H}_{1}$ terima. Baik atau buruknya mutu lulusan sekolah dari berbagai jenjang pendidikan juga dipengaruhi oleh berbagai komponen antara lain: organisasi dan manajemen, ketenagaan, ketatausahaan, sarana prasarana, program dan proses, lingkungan dan stakeholder. Mutu pendidikan maupun mutu sekolah sering tertuju kepada mutu lulusannya. Mutu lulusan yang rendah dapat menimbulkan berbagai masalah,seperti lulusan tidak dapat melanjutkan studi pada jenjang yang lebih tinggi, tidak dapat diterima di dunia kerja, diterima bekerja tapi tidak berprestasi, tidak dapat mengikuti perkembangan masyarakat, dan tidak produktif. Lulusan yang tidak produktif akan menjadi beban masyarakat, menambah biaya kehidupan, dan kemungkinan akan menjadi warga yang tersisih dari masyarakat. ${ }^{55}$

\section{SIMPULAN}

Terdapat pengaruh pengaruh persepsi guru terhadap kepemimpinan kepala sekolah terhadap kinerja guru dengan nilai signifikansinya sebesar 0.00. Sedangkan besarnya korelasi koefisien pengaruh persepsi guru terhadap kepemimpinan kepala sekolah $\left(\mathrm{X}_{1}\right)$ terhadap kinerja guru (Y). Selain itu besarnya nilai pengaruh persepsi guru terhadap kepemimpinan kepala sekolah sebesar 0,356 artinya mengandung pengertian bahwa $35,60 \%$ sumbangan persepsi guru terhadap kepemimpinan kepala sekolah terhadap kinerja guru, sedangkan sisanya $64,4 \%$ yang dipengaruhi oleh faktor yang lain (100\%$35,6 \%)$. Terdapat pengaruh motivasi kerja terhadap kinerja guru dengan nilai signifikansinya sebesar 0.00 . Sedangkan besarnya korelasi koefisien pengaruh motivasi kerja $\left(\mathrm{X}_{2}\right)$ terhadap kinerja guru $(\mathrm{Y})$ sebesar $47.10 \%$ artinya pengaruh antara variabel motivasi kerja $\left(\mathrm{X}_{2}\right)$ terhadap kinerja guru $(\mathrm{Y})$ artinya memiliki kekutan pengaruh antara variabel motivasi kerja $\left(\mathrm{X}_{2}\right)$ terhadap kinerja guru $(\mathrm{Y})$. Terdapat pengaruh kompetensi guru terhadap kinerja guru dengan nilai signifikansinya sebesar 0.00 . Sedangkan besarnya korelasi koefisien pengaruh kompetensi guru $\left(\mathrm{X}_{3}\right)$ terhadap kinerja guru $(\mathrm{Y})$ sebesar $31.20 \%$ artinya pengaruh antara variabel kompetensi guru $\left(\mathrm{X}_{3}\right)$ terhadap kinerja guru $(\mathrm{Y})$ artinya memiliki kekutan pengaruh antara variabel kompetensi guru $\left(\mathrm{X}_{3}\right)$ terhadap kinerja

\footnotetext{
${ }^{55}$ Mohamad Zamroni, Nurkolis dan Yovitha Yuliejantiningsih, Pengaruh Gaya Kepemimpinan Kepala Sekolah Dan Motivasi Kerja Guru Terhadap Kinerja Guru Smp Sekecamatan Kersana Kabupaten Brebes,
} 
guru (Y). Hasil pengujian tersebut mengandung makna bahwa kompetensi guru menentukan kinerja guru dan terdapat pengaruh persepsi guru tentang kepemimpinan kepala madrasah, motivasi kerja, kompetensi guru terhadap kinerja Guru secara bersama dengan nilai signifikansinya sebesar 0.035 .

\section{DAFTAR PUSTAKA}

A. Ahmadi, (1987). Pendidikan Dari Masa Ke Masa (Bandung: CV Armiko, 1987)

Alimi, 'Teachers' Perception of Principals' Leadership Effectiveness in Public and Private Secondary Schools in Ondo State', 2011, 7 (p. hlm 22).

Alwi Hasan, dkk, Kamus Besar Bahasa Indonesia (Jakarta: Departemen Pendidikan Nasional Balai Pustaka, 2005)

Anis Syamsu Rizal, 'Pengaruh Motivasi Kerja dan Kedisiplinan Terhadap Kinerja Guru

SMP', Jurnal Ulul Albab, $23.1 \quad$ (2019), $15 \quad$ (p. hlm 17) <https://doi.org/10.31764/jua.v23i1.658>.

Anwar, "Pengelolaan Pembiayaan Pendidikan: Studi Efektifitas Kepemimpinan Kepala Sekolah."

Atiqullah, (2011). "Kepemimpinan Kepala Sekolah Dalam Mengelola Kelas Unggulan," Nuansa 8, no. 1 .

Baharuddin dan Esa Nur Wahyuni, (2010) . Teori Belajar \& Pembelajaran (Yogyakarta: Ar-Ruz Media)

Barnawi dan Mohammad Ariffin, (2012). Etika dan Profesi Kependidikan (Yogyakarta: Ar-Ruz Media)

Bimo Walgito, (2014). Pengantar Psikologi Umum (Surabaya: Bina Ilmu)

Burhanuddin, (2014). Analisis Administrasi, Mmanajemen dan Kepemimpinan Pendidikan (Jakarta: Bumi Aksara,)

Dita Anggrayni, Hery Sawiji, and Susantiningrum Susantiningrum, 'Pengaruh Motivasi Kerja Dan Lingkungan Kerja Terhadap Kinerja Guru SMK Pancasila 6 Jatisrono Kecamatan Jatisrono Kabupaten Wonogiri', JIKAP (Jurnal Informasi Dan Komunikasi Administrasi $\quad$ Perkantoran), $2.2 \quad$ (2018) <https://jurnal.uns.ac.id/JIKAP/article/view/20800> [accessed 30 July 2020].

Djati Handajani, 'Analisis Peningkatan Kinerja Guru Berdasarkan Diklat Dan Kompensasi Melalui Kepuasan Kerja Sebagai Variabel Intervening (Studi Kasus Pada Smp Negeri Sub Rayon Jakenan Kabupaten Pati)' (unpublished Masters, 
Universitas Muria Kudus, 2016) <http://eprints.umk.ac.id> [accessed 28 July 2020].

Ermi Sola, 'SEBUAH REFLEKSI : Efektivitas Kerja Pimpinan', Idaarah: Jurnal Manajemen Pendidikan, $1.2 \quad$ (2017), p. hlm 243 $<$ https://doi.org/10.24252/idaarah.v1i2.4267>.

Fery Desrian Octama, 'Pengaruh Persepsi Guru Tentang Kepemimpinan Kepala Sekolah, Komunikasi, Dan Motivasi Terhadap Kinerja Guru SMP Negeri 1 Batu Brak Lampung Barat' (unpublished Skripsi di Publikasikan, Lampung, Fakultas Keguraan dan Pendidikan, 2018) <http://digilib.unila.ac.id/31202/> [accessed 27 July 2020].

Fitriyasni dan Marlis Safrida, "Pengaruh Gaya Kepemimpinan Partisipatif Kepala Sekolah Terhadap Motivasi Kerja Guru," FITRA 3, no. 2 (2017).

H Ade Sobandi, 'Pengaruh Kompetensi Guru Terhadap Kinerja Mengajar Guru SMKN Bidang Keahlian Bisnis dan Manajemen di Kota Bandung', 9.17 (2010), 10 (p. hlm.31).

Hamzah B. Uno, (2006). Teori Motivasi dan Pengukurannya (Jakarta: Bumi Aksara, 2009), 72.A.M Sardiman, Interaksi dan Motivasi Belajar Mengajar (Jakarta: CV. Rajawali).

Hary Susanto, 'Faktor-Faktor Yang Mempengaruhi Kinerja Guru Sekolah Menengah Kejuruan', Jurnal Pendidikan Vokasi, 2.2 <https://doi.org/10.21831/jpv.v2i2.1028>.

Hasil Observasi di MTs Negeri Kabupaten Sambas, pada tanggal 5 Januari 2020

Husaini Usman, (2008) Manajemen: Teori, Praktik dan Riset Pendidikan (Jakarta: Bumi Aksara)

J.B. Situmorang dan Winarno, (2008). Pendidikan Profesi dan Sertifikasi Pendidik (Klaten: Macanan Jaya Cemerlang,)

Jamil Suprihatiningkrum, (2014), Guru Profesional: Pedoman Kinerja, Kualifikasi \& Kompetensi Guru (Yogyakarta: Ar-Ruz Media,.

Jejen Musfah, (2011), Peningkatan Kompetensi Guru (Jakarta: Kencana,.

Jejen Musfah, (2012) Peningkatan Kompetensi Guru: Melalaui Pelatihan dan Sumber Belajar Teori dan Praktik (Jakarta: Kencana,.

Komang Septia Cahya Ningrum, 'Pengaruh Kompetensi Guru Terhadap Kinerja Guru SMP Negeri 6 Singaraja', 7 (2016), 12. 
Laeli Kurniati, 'Pengaruh Supervisi Kepala Sekolah Dan Motivasi Kerja Terhadap Kinerja Guru SMK Negeri 1 Purbalingga' (unpublished PhD Thesis, Universitas Negeri Semarang, 2007).

lilik Kurniasih, 'Pengaruh Kompetensi Guru, Iklim Organisasi dan Supervisi Akademik Kepala Sekolah Terhadap Kinerja Guru Mata Pelajaran Pendidikan Agama Islam Sekolah Dasar Negeri Se-Kecamatan Sukoharjo Tahun Pelajaran 2017/ 2018', 187 (p. hlm.118).

Moh Uzer Usman, (2005), Menjadi Guru Profesional (Bandung: Rosdakarya)

Mohamad Zamroni, Nurkolis dan Yovitha Yuliejantiningsih, Pengaruh Gaya Kepemimpinan Kepala Sekolah Dan Motivasi Kerja Guru Terhadap Kinerja Guru Smp Sekecamatan Kersana Kabupaten Brebes,

Mohammad Asrori, (2009). Psikologi Pembelajaran (Bandung: CV. Wacana Prima,

Muchlish Huda, "Tugas Kepemimpinan Kepala Sekolah Dalam Manajemen Berbasis Sekolah," al-Afkar, Journal for Islamic Studies 1, no. 2 (2018): hlm. 46-54.

Muhammad Izzuddin Taufiq, (2006). Panduan Lengkap dan Praktis Psikogi Islam (Jakarta: Gema Insani Press.

Muhibinsyah, (1999). Psikologi Belajar (Jakarta: Logos)

Mulyasa, (2007). Menjadi Kepala Sekolah Profesional (Bandung: PT. Remaja Rosda Karya.

Mulyasa, Menjadi Kepala Sekolah Profesional. andung: PT. Remaja Rosda Karya, (2007), hlm. 90.

Ngalim Purwanto, (2006). Psikologi Pendidikan (Bandung: Remaja Rosdakarya)

Ni Putu Mega Lusiana, 'Pengaruh Persepsi Guru Tentang Kepemimpinan Kepala Sekolah Terhadap Kinerja Guru Di Sma Laboratorium Undiksha Singaraja Tahun Pelajaran 2017', Jurnal Pendidikan Ekonomi Undiksha, 10.2 (2019), 440-49 <https://doi.org/10.23887/jjpe.v10i2.20076>.

Nyoto, (2009). Buku Ajar Manajemen Sumber Daya Manusia (Ponorogo, Indonesia: Uwais Inspirasi Indonesia,

.Marihot Tua Efendi Hariandja, Manajemen Sumber Daya Manusia: Pengadaan, Pengembangan, Pengkompensasian, dan Peningkatan Produktivitas Pegawai (Jakarta: Grasindo, 2002), hlm. 1.

Rahmawati Setia Utami and Tarsis Tarmudji, 'Pengaruh Lingkungan Kerja Dan Kompensasi Kerja Melalui Motivasi Kerja Sebagai Variabel Intervening Terhadap Kinerja Guru Di SMA Negeri 7 Semarang Pada Tahun 2013/2014', Economic Education Analysis Journal, 3.2 (2014). 
Rasto Rasto and Siti Yulianti Maulani, 'Satisfaction and Motivation as Determinants of Teacher Performance', Jurnal Pendidikan Bisnis Dan Manajemen, 5.1 (2019), 1121 (p. hlm 18) <https://doi.org/10.17977/um003v5i12019p011>.

Rusman, (2009) Manajemen Kurikulum (Jakarta: Rajawali Pers).

Satria Mulyawan, 'Pengaruh Persepsi Kepemimpinan Kepala Sekolah Dan Motivasi Kerja Terhadap Kinerja Guru Ekonomi SMA Kota Tegal' (unpublished PhD Thesis, Universitas Negeri Semarang, 2011).

Slamet Riyadi and Aria Mulyapradana, 'Pengaruh Motivasi Kerja Terhadap Kinerja Guru Radhatul Atfal di Kota Pekalongan', Jurnal LITBANG Kota Pekalongan, 13 (2017), 106-17.

Sudarman Danim, (2010). Kepemimpinan Pendidikan Kepemimpinan Jenius ( IQ +EQ), Etika, Perilaku Motivasional, dan Mitos (Bandung: Alfabeta)

Sudarwan Danim, (2011). Pengembangan Profesi Guru (Jakarta: Kencana)

Sugiyono, (2011). Metode Penelitian Pendidikan; Pendekatan Kuantitatif, Kualitatif dan $R \& D$

Suparman, (2019). Kepemimpinan Kepala Sekolah dan Guru: Sebuah Pengantar Teoritik (Indonesia: Uwais Inspirasi Indonesia

Titin Eka Ardiana, 'Pengaruh Motivasi Kerja Guru Terhadap Kinerja Guru Akuntansi SMK di Kota Madiun', JURNAL AKUNTANSI DAN PAJAK, 17.02 (2017) $<$ https://doi.org/10.29040/jap.v17i02.11>.

Tri Andjarwati, "Motivasi dari Sudut Pandang Teori Hirarki Kebutuhan Maslow, Teori Dua Faktor Herzberg, Teori X Y Mc Gregor, dan Teori Motivasi Prestasi Mc Clelland," JMM17 Jurnal Ilmu Ekonomi \& Manajemen 1, no. 1 (2015): hlm 48.

Triamto, (2011). Pengantar Penelitian Pendidikan bagi Pengembangan Profesi Pendidikan \&Tenaga Kependidikan (Jakarta: Kencana)

Zafri Zamzam, Syekh Muhammad Arsyad Al-Banjary: Sebagai Ulama Juru Da'wah Sejarah Penyiaran Islam di Kalimantan Abad 13 H/18 M dan Pengaruhnya di Asia Tenggara (Banjarmasin: Antasari Press, 2018), 